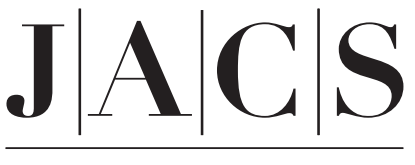

A R T I C L E S

Published on Web 05/07/2008

\title{
Sodium Alanate Nanoparticles - Linking Size to Hydrogen Storage Properties
}

\author{
Cornelis P. Baldé, Bart P.C. Hereijgers, Johannes H. Bitter, ${ }^{*}$ and Krijn P. de Jong ${ }^{\star}$ \\ Inorganic Chemistry and Catalysis, Department of Chemistry, Utrecht University, \\ 3584 CA Utrecht, The Netherlands
}

Received November 28, 2007; E-mail: k.p.dejong@uu.nl; j.h.bitter@uu.nl

\begin{abstract}
Important limitations in the application of light metal hydrides for hydrogen storage are slow kinetics and poor reversibility. To alleviate these problems doping and ball-milling are commonly applied, for $\mathrm{NaAlH}_{4}$ leading to particle sizes down to $150 \mathrm{~nm}$. By wet-chemical synthesis we have prepared carbon nanofiber-supported $\mathrm{NaAlH}_{4}$ with discrete particle size ranges of $1-10 \mu \mathrm{m}, 19-30 \mathrm{~nm}$, and 2-10 nm. The hydrogen desorption temperatures and activation energies decreased from $186{ }^{\circ} \mathrm{C}$ and $116 \mathrm{~kJ} \cdot \mathrm{mol}^{-1}$ for the largest particles to $70{ }^{\circ} \mathrm{C}$ and $58 \mathrm{~kJ} \cdot \mathrm{mol}^{-1}$ for the smallest particles. In addition, decreasing particle sizes lowered the pressures needed for reloading. This reported size-performance correlation for $\mathrm{NaAlH}_{4}$ may guide hydrogen storage research for a wide range of nanostructured light (metal) hydrides.
\end{abstract}

\section{Introduction}

Hydrogen storage materials need to fulfill strict requirements with respect to safety, capacity, and kinetics for on-board application. ${ }^{1}$ Lightweight metal hydrides are considered as storage media, but kinetic constraints limit their application. A promising approach to address this issue is to reduce the particle size of the metal hydride to the nanometer range, resulting in enhanced kinetics without the need of a catalyst. ${ }^{2,3}$ Nanoparticles often display modified behavior compared to bulk particles and are applied for instance in catalysis, ${ }^{4,5}$ chemical sensors, ${ }^{6}$ or optics. $^{7,8}$ Here, we focus on size effects of sodium alanate $\left(\mathrm{NaAlH}_{4}\right)$ particles. The structure and hydrogen storage properties of $\mathrm{NaAlH}_{4}$ have been studied extensively over the past 10 years as can be concluded from several reviews. ${ }^{9-12}$ This complex hydride can, therefore, be considered as a model system to arrive at more generally applicable conclusions on size effects for hydrogen storage materials.

(1) Schlapbach, L.; Züttel, A. Nature 2001, 414, 353-358.

(2) Baldé, C. P.; Hereijgers, B. P. C.; Bitter, J. H.; de Jong, K. P. Angew. Chem., Int. Ed. 2006, 45, 3501-3503.

(3) Gutowska, A.; Li, L.; Shin, Y.; Wang, C. M.; Li, X. S.; Linehan, J. C.; Smith, R. S.; Kay, B. D.; Schmid, B.; Shaw, W.; Gutowski, M.; Autrey, T. Angew. Chem., Int. Ed. 2005, 44, 3578-3582.

(4) Bezemer, G. L.; Bitter, J. H.; Kuipers, H. P. C. E.; Oosterbeek, H.; Holewijn, J. E.; Xu, X.; Kapteijn, F.; van Dillen, A. J.; de Jong, K. P. J. Am. Chem. Soc. 2006, 128, 3956-3964.

(5) Bell, A. T. Science 2003, 299, 1688-1691.

(6) Kong, J.; Franklin, N. R.; Zhou, C.; Chapline, M. G.; Peng, S.; Cho, K.; Dai, H. Science 2000, 287, 622-625.

(7) Xi, J.-Q.; Kim, J. K.; Schubert, E. F. Nano Lett. 2005, 5 (7), 1385 1387.

(8) Tong, L.; Lou, J.; Gattass, R.; He, S.; Chen, X.; Liu, L.; Mazur, E. Nano Lett. 2005, 5 (2), 259-262.

(9) Schüth, F.; Bogdanovic, B.; Felderhof, M. Chem. Commun. 2004, 37, 2249-2258.

(10) Grochala, W.; Edwards, P. P. Chem. Rev. 2004, 104 (3), 1283-1315.

(11) Orimo, S.; Nakamori, Y.; Eliseo, J. R.; Züttel, A.; Jensen, C. M. Chem. Rev. 2007, 107 (10), 4111-4132.

(12) Bogdanovic, B.; Eberle, U.; Felderhoff, M.; Schüth, F. Scr. Mater. 2007, 56, 813-816.
Particle sizes of metal hydrides are usually decreased by ball milling, for $\mathrm{NaAlH}_{4}$ preferably in the presence of a Ti-based catalyst. ${ }^{13-15}$ However, with that method the particle size is difficult to control, the size distribution is broad, and the smallest particle size achievable is typically 150 to $200 \mathrm{~nm}$ for $\mathrm{NaAlH}_{4}{ }^{15}$ Therefore another preparation method is needed to study particles smaller than $150 \mathrm{~nm}$. Nanoparticles are regularly synthesized by deposition of a metal precursor onto a support material in heterogeneous catalysis. ${ }^{16,17}$ In the field of hydrogen storage, this approach has been demonstrated to facilitate $\mathrm{H}_{2}$ desorption rates for $\mathrm{NaAlH}_{4},{ }^{2}$ nanoscaffolded $\mathrm{NH}_{3} \mathrm{BH}_{3},{ }^{3,18}$ and $\mathrm{LiBH}_{4} \cdot{ }^{19,20}$ However, the particle size of the hydrides used in those studies was not reported. Here, we present an extensive study using alternative preparation routes, characterization of the $\mathrm{NaAlH}_{4}$ particle size, and the effect of particle size on hydrogen storage properties. The $\mathrm{NaAlH}_{4}$ particles were supported on Carbon Nanofibers (CNF). Particle sizes were determined using Scanning Electron Microscopy (SEM), Transmission Electron Microscopy (TEM), and quantitative X-ray Photoelectron Spectroscopy (XPS). The hydrogen desorption properties of the samples were linked to the particle sizes, and $\mathrm{H}_{2}$ absorption characteristics were compared to those of ball milled $\mathrm{TiCl}_{3}-\mathrm{NaAlH}_{4}$.

(13) Bogdanovic, B.; Felderhoff, M.; Pommerin, A.; Schüth, F.; Spielkamp, N. Adv. Mater. 2006, 18, 1198-1201.

(14) Fichtner, M.; Fuhr, O.; Kircher, O.; Rothe, J. Nanotechnology 2003, 14 (7), 778-785.

(15) Brinks, H. W.; Hauback, B. C.; Srinivasan, S. S.; Jensen, C. M. J. Phys. Chem. B 2005, 109, 15780-15785.

(16) Pan, X.; Fan, Z.; Chen, W.; Ding, Y.; Luo, H.; Bao, X. Nat. Mater. 2007, 6, 507-511.

(17) Sietsma, J. R. A.; Meeldijk, J. D.; den Breejen, J. P.; Versluijs-Helder, M.; van Dillen, A. J.; de Jongh, P. E.; de Jong, K. P. Angew. Chem., Int. Ed. 2007, 46, 4547-4549.

(18) Feaver, A.; Sepehri, S.; Shamberger, P.; Stowe, A.; Autrey, T.; Cao, G. J. Phys. Chem. B 2007, 111 (26), 7469-7472.

(19) Züttel, A.; Wenger, P.; Rentsch, S.; Sudan, P.; Mauron, P.; Emmenegger, C. J. Power Sources 2003, 118, 1-7.

(20) Vajo, J. J.; Olson, G. L. Scr. Mater. 2007, 56 (10), 829-834. 


\section{Experimental Section}

Fishbone CNF of 20-30 nm in diameter were grown from $5 \mathrm{wt}$ $\% \mathrm{Ni} / \mathrm{SiO}_{2}\left(425-850 \mu \mathrm{m} \mathrm{SiO} \mathrm{S}_{2}\right.$ particles) using $\mathrm{H}_{2} / \mathrm{CO}$ as described by Van der Lee et al. ${ }^{21}$ After CNF synthesis, $\mathrm{SiO}_{2}$ was removed by refluxing the product in $1 \mathrm{M} \mathrm{KOH}$. Subsequently, Ni was removed by refluxing the product in fresh concentrated $\mathrm{HCl}$. After each refluxing step, the CNF were thoroughly washed with demineralized water. Finally, the $\mathrm{CNF}$ were dried in an inert atmosphere at $500{ }^{\circ} \mathrm{C}$ and stored in a glovebox for further use. The CNF prepared in this way contained a low concentration $(<0.02$ $\mathrm{mmol} \cdot \mathrm{g}^{-1}$ ) of oxygen-containing groups on the surface and had a specific surface area of $130 \mathrm{~m}^{2} \cdot \mathrm{g}^{-1} \cdot 22$

All further sample handling was conducted under a dry and inert atmosphere using either Schlenk equipment or an $\mathrm{N}_{2}$ filled glovebox with a circulation purifier. $\mathrm{NaAlH}_{4}(90 \%$ Sigma Aldrich) was purified by dissolving it in dried THF followed by filtration to remove insoluble contaminants. The pure Alanate was obtained as a white powder after evaporation of the THF under reduced pressure. It was stored in a glovebox and used within 1 day.

$\mathrm{NaAlH}_{4}$ was deposited on CNF by pore volume $\left(1 \mathrm{~mL} \cdot \mathrm{g}^{-1}\right)$ impregnation using dried THF as a solvent. Samples with $\mathrm{NaAlH}_{4}$ loadings of 2 and $8 \mathrm{wt} \%$ were prepared by adapting the concentration of $\mathrm{NaAlH}_{4}$ in the impregnation solution. Both samples were dried at reduced pressure $(6 \mathrm{mbar})$ while heating from -40 to $-15{ }^{\circ} \mathrm{C}$ over a period of $3 \mathrm{~h}$; this is denoted as low temperature drying. In addition, a sample was prepared with a loading of $9 \mathrm{wt}$ $\%$ which was dried at room temperature for $5 \mathrm{~min}$ at $6 \mathrm{mbar}$ (denoted as room-temperature drying).

Temperature Programmed Desorption (TPD) of $\mathrm{H}_{2}$ was performed using a Micromeritics AutoChem II 2920. A 200 to 400 $\mathrm{mg}$ amount of sample was loaded in the reactor and heated, in a $25 \mathrm{~mL} / \mathrm{min}$ Ar flow while heating from -20 to $300{ }^{\circ} \mathrm{C}$. Reloading of the samples was performed in a high pressure magnetic suspension balance from Rubotherm. ${ }^{23,24}$ For " $19-30 \mathrm{~nm} \mathrm{NaAlH}_{4}$ ", $250 \mathrm{mg}$ sample were loaded in the balance. For ball milled $\mathrm{TiCl}_{3}-\mathrm{NaAlH}_{4}$ (prepared via procedure described by Haiduc et al., $\left.{ }^{25} \mathrm{Ti} / \mathrm{Al}=0.05 \mathrm{at} / \mathrm{at}\right) 4 \mathrm{mg}$ were loaded. Prior to the uptake measurement, the sample was desorbed at 0.1 bar $\mathrm{H}_{2}$ pressure (99.999\% purity) at $250{ }^{\circ} \mathrm{C}$. Next, the temperature was lowered to the absorption temperature $\left(115^{\circ} \mathrm{C}\right)$ and equilibrated for $1 \mathrm{~h} . \mathrm{H}_{2}$ uptake was monitored by the weight increase of the sample during the subsequent pressure increase $\left(1.38 \mathrm{bar} \cdot \mathrm{min}^{-1}\right)$ to $100 \mathrm{bar} \mathrm{H}_{2}$ pressure. Hydrogen uptake and desorption were determined after subtracting the weight changes of an empty sample holder and applying a buoyancy correction due to the volume of the sample.

For SEM studies, samples were crushed by mortar and pestle in a glovebox. SEM studies were performed using an FEI XL30 FEG electron microscope equipped with an EDX detector. The crushed sample was fixed to a double-sided carbon tape and transported in an $\mathrm{N}_{2}$ atmosphere to the microscope. Mounting the sample into the microscope involved brief (less than $1 \mathrm{~min}$ ) exposure to air. In SEM studies we have limited beam damage of the sodium alanate particles by beam focusing on a certain part of the specimen followed by moving to a fresh part of the sample that was directly imaged. HR-TEM and STEM images were obtained using a Tecnai $20(200 \mathrm{kV})$ equipped with an EDX and an HAADF detector. All samples for TEM were desorbed at $300{ }^{\circ} \mathrm{C}$ prior to analysis after which they were passivated in air and mounted to the sample holder.

(21) van der Lee, M. K.; van Dillen, A. J.; Bitter, J. H.; de Jong, K. P. J. Am. Chem. Soc. 2005, 127 (39), 13573-13582.

(22) Toebes, M. L.; van Heeswijk, E. M. P.; Bitter, J. H.; van Dillen, A. J.; de Jong, K. P. Carbon 2004, 42 (2), 307-315.

(23) Dreisbach, F.; Seif, R.; Lösch, H. W. J. Therm. Anal. Calorim. 2003, $71,73-82$.

(24) Lösch, H. W.; Kleinrahm, R.; Wagner, W. Neue Magnetschwebewaagen für gravimertrische Messungen in der Verfahrentechnik; VDIVerslag: Düsseldorf, 1994.

(25) Haiduc, A. G.; Stil, H. A.; Schwarz, M. A.; Paulus, P.; Geerlings, J. J. C. J. Alloys Compd. 2005, 393 (1-2), 252-263.
The rationale for sample desorption and passivation relates to inevitable beam damage (particle instability and Na-evaporation) to sodium alanate in TEM. ${ }^{26-28}$ Desorption and passivation appeared to maintain particle size (see section 3.1) although particle morphology may have changed.

X-ray Photoelectron Spectroscopy (XPS) spectra were acquired from a Perkin-Elmer (PHI) model 5580 spectrometer using $\mathrm{Al} \mathrm{K \alpha}$ radiation. Samples were desorbed at $300{ }^{\circ} \mathrm{C}$, passivated in ambient air, crushed, and pressed on double-sided carbon tape. Using the $\mathrm{Al} / \mathrm{C}$ atomic ratio it was found that the details of passivation (duration, oxygen concentration) had little effect if any $(<10 \%$ relative) on the ratios obtained. Shirley backgrounds were subtracted from the raw data to obtain the areas of the $\mathrm{C}_{1 \mathrm{~s}}, \mathrm{Al}_{2 \mathrm{p}}$, and $\mathrm{Na}_{1 \mathrm{~s}}$ signals. The inelastic mean free path of photoelectrons generated in $\mathrm{NaAlH}_{4}$ is very small, i.e., $3.1 \mathrm{~nm}$ for $\mathrm{C}_{1 \mathrm{~s}}, 2.6 \mathrm{~nm}$ for $\mathrm{Al}_{2 \mathrm{p}}$, and $1.1 \mathrm{~nm}$ for $\mathrm{Na}_{1 \mathrm{~s}}$. Thus, the intensity ratios $\mathrm{Al}_{2 \mathrm{p}} / \mathrm{C}_{1 \mathrm{~s}}$ and $\mathrm{Na}_{1 \mathrm{~s}} / \mathrm{C}_{1 \mathrm{~s}}$ together with the loading and $\mathrm{CNF}$ specific surface area were used to calculate the dispersion of $\mathrm{Na}$ and $\mathrm{Al}$ on the $\mathrm{CNF}$ based on the model by Kuipers et al. ${ }^{29,30}$ Particle sizes obtained earlier for Co on $\mathrm{CNF}^{4}$ with this model were in good agreement with TEM, EXAFS, and $\mathrm{H}_{2}$ chemisorption results.

In situ powder X-ray diffraction data were recorded on a BrukerAXS D-8 diffractometer using $\mathrm{Co}_{\mathrm{K} \alpha 1,2}$ radiation. The sample was crushed, loaded in an Anton-Paar reaction chamber in the glovebox, closed, and transported to the diffractometer. The reaction chamber was connected to a gas system, and measurements were carried out in flowing $\mathrm{N}_{2}$ with a ramp of $2{ }^{\circ} \mathrm{C} \cdot \mathrm{min}^{-1}$ to $250{ }^{\circ} \mathrm{C}$.

\section{Results and Discussion}

3.1. Preparation and Structure of Nano-NaAlH 4 . The CNF support material used in this study consisted of entangled fibers with diameters between 20 and $30 \mathrm{~nm}$ resulting in a porous skein. Figure 1A displays a typical SEM micrograph of a CNF skein to illustrate its morphology. The CNF skeins were impregnated with a solution of $\mathrm{NaAlH}_{4}$ in THF until the pore volume was completely filled. $\mathrm{NaAlH}_{4}$ was deposited on the CNF by subsequent drying. The drying conditions (temperature) and $\mathrm{NaAlH}_{4}$ loading determined the size of $\mathrm{NaAlH}_{4}$ particles on the CNF. Since the samples used in SEM have been exposed to air, particle morphology may have been affected. The size of the particles, however, was qualitatively confirmed by XRD patterns (data not shown) that displayed sharp lines and thus particles $>100 \mathrm{~nm}$. As shown below for much smaller particles, the sizes obtained from SEM/TEM were quantitatively supported by XRD and XPS. Drying at room temperature under reduced pressure of 9 wt $\% \mathrm{NaAlH}_{4}$ on $\mathrm{CNF}$ resulted in particles varying from $1 \mu \mathrm{m}$ (Figure 1B) to $10 \mu \mathrm{m}$ (Figure 1C) at the outer surface of the CNF skeins. This sample will be referred to as " $1-10$ $\mu \mathrm{m} \mathrm{NaAlH} \mathrm{N}_{4}$.

A second sample with a comparable loading of 8 wt $\%$ $\mathrm{NaAlH}_{4}$ was dried at low temperature $\left(-40{ }^{\circ} \mathrm{C}\right.$ to $\left.-15^{\circ} \mathrm{C}\right)$. In that sample, SEM did not reveal the presence of large $\mathrm{NaAlH}_{4}$ particles (Figure 1D). However, the fibers, shown in Figure 1D for a relatively porous part of the sample, had been thickened

(26) Graham, D. D.; Culnane, L. F.; Sulic, M.; Robertson, C. M. J. I. M. J. Alloys Compd. 2007, 446-447, 255-259.

(27) Andrei, C. M.; Walmsley, J. C.; Brinks, H. W.; Holmestad, R.; Srinivasan, S. S.; Jensen, C. M.; Haubac, B. C. Appl. Phys. A 2005, 80, 709-715.

(28) Felderhoff, M.; Klementiev, K.; Grunert, W.; Spliethoff, B.; Tesche, B.; Colbe, J. M. B. V.; Bogdanovic, B.; Hartel, M.; Pommerin, A.; Schüth, F.; Weidenthaler, C. Phys. Chem. Chem. Phys. 2004, 6, 43694374.

(29) Kuipers, H. P. C. E. Solid State Ion. 1985, 16, 15-21.

(30) Kuipers, H. P. C. E.; Leuven, H. C. E. V.; Visser, W. M. Surf. Interface Anal. 1986, 8 (6), 235-242. 


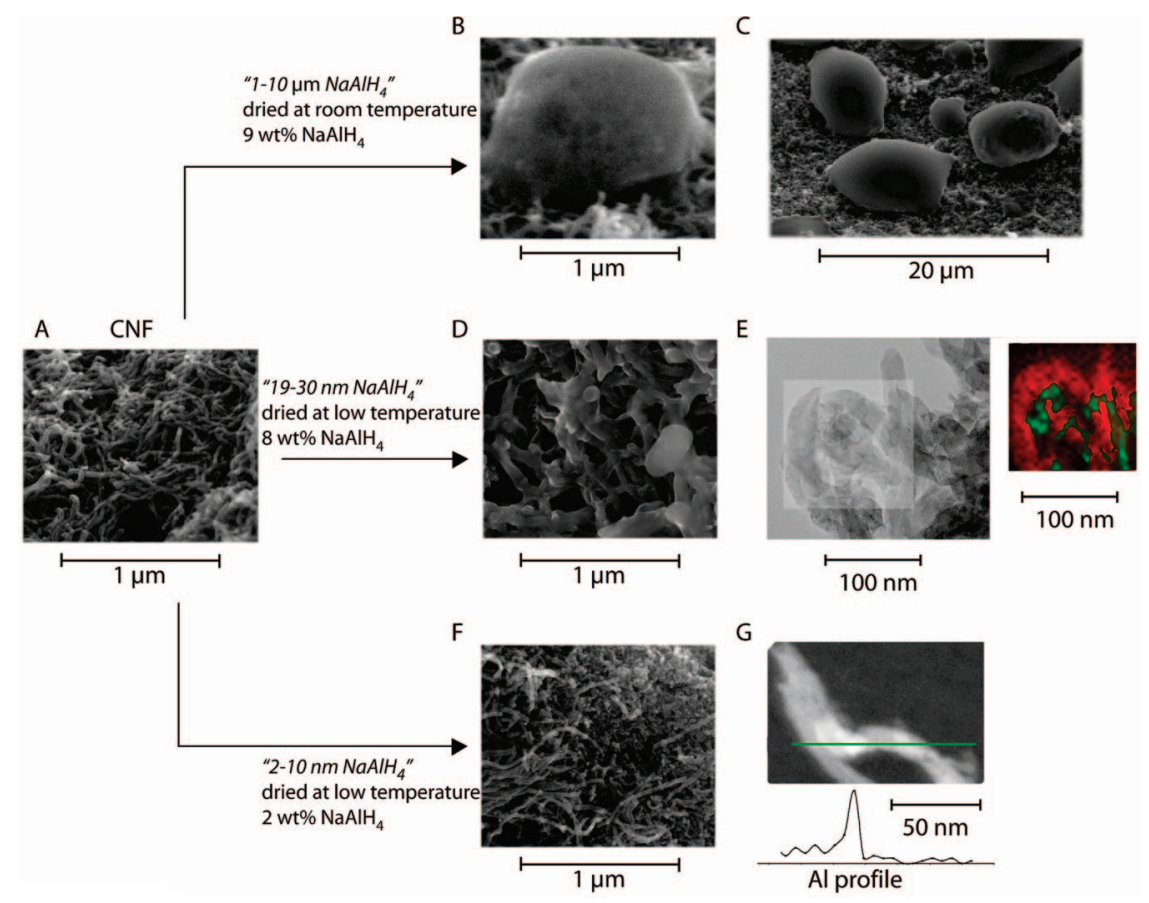

Figure 1. Overview of $\mathrm{NaAlH}_{4} / \mathrm{CNF}$ samples. (A) CNF skein prior to impregnation; (B and C) SEM micrographs of " $1-10 \mu \mathrm{m} \mathrm{NaAlH} 4$ "; (D) SEM micrograph of "19-30 nm NaAlH 4 "; (E) TEM and an EDX elemental map of highlighted region (C in red and Al in green) for "19-30 nm NaAlH 4 " after desorption; (F) SEM micrograph of "2-10 nm NaAlH 4 "; (G) TEM micrographs with Al profile of "2-10 nm NaAlH" after desorption.

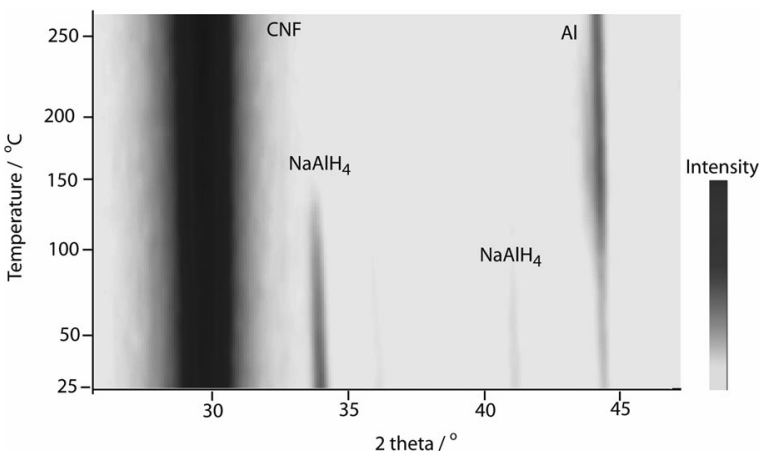

Figure 2. In situ X-ray diffraction of " $19-30 \mathrm{~nm} \mathrm{NaAlH}_{4}$ " with heating ramp of $2{ }^{\circ} \mathrm{C} \cdot \mathrm{min}^{-1}$.

by $\mathrm{NaAlH}_{4}$ deposition suggesting $\mathrm{NaAlH}_{4}$ present on the individual fibers. A particle size could not be derived from SEM but required XRD, TEM, and XPS of the sample after hydrogen desorption; i.e., $\mathrm{NaAlH}_{4}$ decomposed to $\mathrm{Al}$ and $\mathrm{NaH}^{31}$ Whether the particle size of the material after desorption represented the original particle size has been verified with XRD.

Figure 2 shows a two-dimensional plot of the XRD patterns of the $8 \mathrm{wt} \% \mathrm{NaAlH}_{4}$ as a function of the desorption temperature. In the fresh material the diffractions of $\mathrm{CNF}, \mathrm{NaAlH}_{4}$, and $\mathrm{Al}$ were detected. During heating the intensity of the $\mathrm{NaAlH}_{4}$ diffractions decreased and became zero above $150{ }^{\circ} \mathrm{C}$. The disappearance of the $\mathrm{NaAlH}_{4}$ diffractions was paralleled by an increase in the $\mathrm{Al}$ diffraction line. From the width of the $\mathrm{NaAlH}_{4}$ and $\mathrm{Al}$ diffraction lines it was established that both the $\mathrm{NaAlH}_{4}$ and $\mathrm{Al}$ particles were on average $22 \mathrm{~nm}$. Therefore, the $\mathrm{Al}$ particle size obtained after decomposition by all techniques coincided with the original $\mathrm{NaAlH}_{4}$ particle size.

Figure 1E shows a TEM micrograph of this sample after desorption together with the $\mathrm{Al}$ and $\mathrm{C}$ elemental maps of the highlighted region. The carbon map followed the structure of the fibers as expected. Al domains were detected on the fibers
Table 1. Atomic ratios and particle size obtained by XPS

\begin{tabular}{cccc}
\hline $\mathrm{NaAlH}_{4}$ loading (wt \%) & $\mathrm{Al} / \mathrm{C}(\mathrm{at} / \mathrm{at})$ & $\mathrm{Na} / \mathrm{C}(\mathrm{at} / \mathrm{at})$ & $\mathrm{Al}(\mathrm{d} / \mathrm{nm})$ \\
\hline 2 & 0.0055 & 0.032 & 2 \\
8 & 0.0071 & 0.059 & 19
\end{tabular}

with sizes between 20 and $30 \mathrm{~nm}$. The particle size of Al was additionally determined using quantitative XPS, which was based on the $\mathrm{Al} / \mathrm{C}$ ratio of desorbed $\mathrm{NaAlH}_{4}$ samples, specific surface area of the $\mathrm{CNF}$ and $\mathrm{NaAlH}_{4}$ loading. ${ }^{29,30}$ The atomic $\mathrm{Al} / \mathrm{C}$ and $\mathrm{Na} / \mathrm{C}$ ratios are listed in Table 1 . When the model was used assuming hemispherical particles, the $\mathrm{Al}$ particles size was calculated to be $19 \mathrm{~nm}$ (Table 1). The high atomic $\mathrm{Na} / \mathrm{C}$ suggested that $\mathrm{NaH}$ was highly, possibly atomically, dispersed. The Al particle size is in agreement with the $20-30 \mathrm{~nm}$ particle size range obtained from TEM (Figure 1E), illustrating the suitability of the XPS model. The sample will be referred to as "19-30 nm $\mathrm{NaAlH}_{4}$ ".

The higher dispersion of $\mathrm{NaH}$ than that of $\mathrm{Al}$, as inferred from XPS, is in agreement with the in situ diffraction experiment shown in Figure 2. It was observed that $\mathrm{NaH}$ was XRD amorphous, whereas Al showed diffraction lines. A possible cause for the higher dispersion is that the interaction of $\mathrm{NaH}$ with the CNF support is considerable larger than the interaction of $\mathrm{Al}$ with the CNF. If a carbon support is absent, $\mathrm{NaH}$ and $\mathrm{Al}$ will not be highly dispersed. Consequently, unsupported $\mathrm{NaAlH}_{4}$ upon desorption will form large $\mathrm{NaH}$ and $\mathrm{Al}$ particles, as was found in other studies for bulk samples with TEM, ${ }^{28} \mathrm{SEM},{ }^{32}$ and XRD. ${ }^{33}$

In the third sample, the fibers were impregnated with a lower concentration of $\mathrm{NaAlH}_{4}$ in solution. The impregnated material

(31) When $\mathrm{NaAlH}_{4}$ is heated it decomposes via the following reactions: $\mathrm{NaAlH}_{4} \leftrightarrow 1 / 3 \mathrm{Na}_{3} \mathrm{AlH}_{6}+{ }^{2} / 3 \mathrm{Al}+\mathrm{H}_{2} \leftrightarrow \mathrm{NaH}+\mathrm{Al}+{ }^{3} / 2 \mathrm{H}_{2}$. The material after desorption was used for XPS and TEM studies since $\mathrm{NaAlH}_{4}$ is not stable under the conditions which TEM and XPS measurements are performed (low pressure and ionizing radiation). 


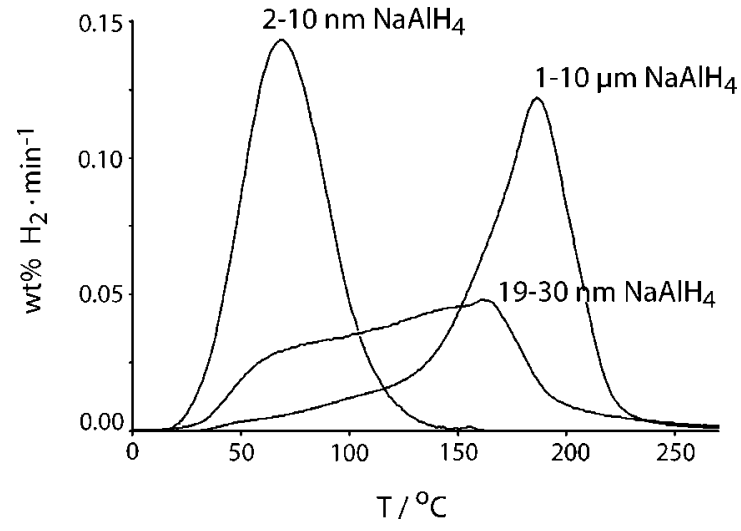

Figure 3. Temperature programmed desorption profiles of $\mathrm{H}_{2}$ for $\mathrm{NaAlH}_{4} /$ $\mathrm{CNF}$ samples under Ar atmosphere. Heating ramp $5^{\circ} \mathrm{C} / \mathrm{min}$.

was dried at low temperature, and the loading was 2 wt \% $\mathrm{NaAlH}_{4}$. SEM only detected the individual CNF fibers in this sample (Figure 1F), indicating that the $\mathrm{NaAlH}_{4}$ particles were small. From STEM-EDX line scans over several single Al particles (one line scan is shown in Figure $1 \mathrm{G}$ ) it was concluded that the upper limit of particle size was $10 \mathrm{~nm}$. XPS shows that the atomic $\mathrm{Al} / \mathrm{C}$ and $\mathrm{Na} / \mathrm{C}$ ratios were significantly larger after normalization to the alanate loading for the $2 \mathrm{wt} \%$ loaded sample than those for the $8 \mathrm{wt} \%$ loaded sample (Table 1). This indicates that the dispersion of $\mathrm{Al}$ and $\mathrm{NaH}$ was higher in the $2 \mathrm{wt} \%$ loaded sample than that for the $8 \mathrm{wt} \%$ sample. When the same quantitative XPS model was applied, it was calculated that the 2 wt \% loaded sample consisted of $2 \mathrm{~nm} \mathrm{Al}$ particles. Such small Al particles could not be inferred from the EDX line scan shown in Figure $1 \mathrm{G}$, as the spatial resolution was insufficient. Therefore, the combination of TEM and XPS provided a $2-10 \mathrm{~nm}$ particle size range, and the sample will be referred to as " $2-10 \mathrm{~nm} \mathrm{NaAlH}$ ".

Thus, we have tuned the $\mathrm{NaAlH}_{4}$ particle sizes in discrete ranges of $2-10 \mathrm{~nm}, 19-30 \mathrm{~nm}$, and $1-10 \mu \mathrm{m}$. A detailed discussion about the influence of the preparation parameters on the particle size can be found in the Supporting Information. The effects of the particle size on $\mathrm{H}_{2}$ desorption and absorption properties are discussed in the next section.

3.2. Size-Performance Relationship. Figure 3 shows the $\mathrm{H}_{2}$ desorption profiles for the three $\mathrm{CNF}$-supported $\mathrm{NaAlH}_{4}$ samples. The temperature at the maximum desorption rate $\left(T_{\max }\right)$ was highest for " $1-10 \mu \mathrm{m} \mathrm{NaAlH} 4$ " $\left(186{ }^{\circ} \mathrm{C}\right)$ followed by "19-30 nm NaAlH 4 " $\left(164{ }^{\circ} \mathrm{C}\right)$ and lowest for " $2-10 \mathrm{~nm} \mathrm{NaAlH} 4$ " (70 $\left.{ }^{\circ} \mathrm{C}\right)$. Thus, the smaller the particles, the lower the $\mathrm{H}_{2}$ desorption temperature. The activation energy for $\mathrm{H}_{2}$ desorption was calculated using a Kissinger analysis that is based on the shifts in $T_{\max }$ with heating rates $(\beta)$ of $0.5,1,2$, and $5^{\circ} \mathrm{C} \cdot \min ^{-1} .34$ For that, $\ln \left(\beta / T_{\max }^{2}\right)$ was plotted versus $1 / T_{\max }$ (see Figure 4 ). The slope of the curve represents $-E_{\mathrm{a}} / R$ in which $R$ is the gas constant. From the slope in Figure 4 it was established that the $E_{\mathrm{a}}$ for $\mathrm{H}_{2}$ desorption was $116 \mathrm{~kJ} \cdot \mathrm{mol}^{-1}$ for " $1-10 \mu \mathrm{m} \mathrm{NaAlH} 4$ ", which is in good agreement with reported values for uncatalyzed bulk $\mathrm{NaAlH}_{4}\left(120 \mathrm{~kJ} \cdot \mathrm{mol}^{-1}\right){ }^{35,36}$ Thus, the $1-10 \mu \mathrm{m} \mathrm{NaAlH}$

(32) Bogdanovic, B.; Brand, R. A.; Marjanovic, A.; Schwickardi, M.; Tolle, J. J. Alloys Compd. 2000, 302, 36-58.

(33) Gross, K. J.; Guthrie, S.; Takara, S.; Thomas, G. J. Alloys Compd. 2000, 297, 270-281

(34) Kissinger, H. E. Anal. Chem. 1957, 29, 1702.

(35) Luo, W.; Gross, K. J. J. Alloys Compd. 2004, 385, 224-231.

(36) Sandrock, G.; Gross, K.; Thomas, G. J. Alloys Compd. 2002, 339, 299-308.

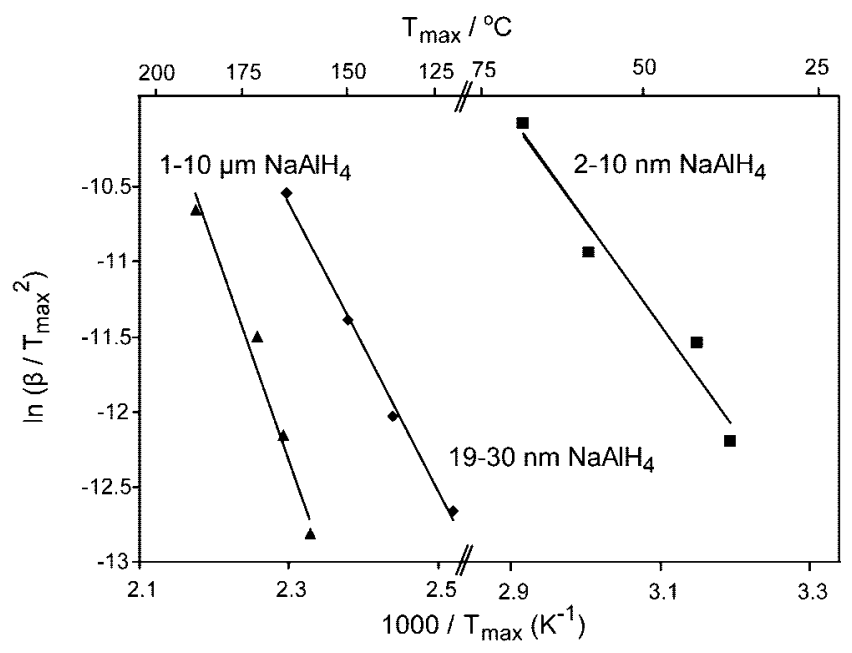

Figure 4. Kissinger plots and temperature at maximum desorption rate $\left(T_{\max }\right)$ for $\mathrm{NaAlH}_{4}$ samples.

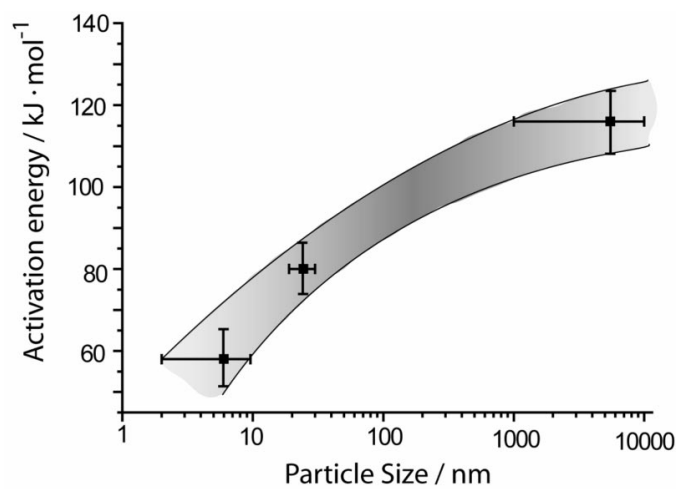

Figure 5. Relation between particle size and activation energy for hydrogen desorption from $\mathrm{NaAlH}_{4} / \mathrm{CNF}$. The spread in the particle size reflects the results from different characterization techniques, and the error bars in activation energies were obtained from linear regression analysis.

particles showed bulk-like $\mathrm{H}_{2}$ desorption behavior. However, the sample desorbed a small amount of $\mathrm{H}_{2}$ below $140{ }^{\circ} \mathrm{C}$ (Figure $3)$. This was probably $\mathrm{H}_{2}$ desorption from a small fraction of the $\mathrm{NaAlH}_{4}$ that was smaller in size (vide infra).

The $\mathrm{H}_{2}$ desorption from " $19-30 \mathrm{~nm} \mathrm{NaAlH}$ " proceeded from 25 to $250{ }^{\circ} \mathrm{C}$. This indicates that a broad particle size distribution was present. Most likely, $\mathrm{H}_{2}$ evolution from 25 to $100{ }^{\circ} \mathrm{C}$ came from a fraction of particles that had a similar size as that for "2-10 nm NaAlH 4 ", since the desorption temperature coincided with that of "2-10 nm NaAlH 4 " (Figure 3). The peak with the $T_{\max }$ at $164{ }^{\circ} \mathrm{C}$ then reflects desorption from the larger (19-30 $\mathrm{nm}) \mathrm{NaAlH}_{4}$ particles. The activation energy for $\mathrm{H}_{2}$ desorption from these particles was $80 \mathrm{~kJ} \cdot \mathrm{mol}^{-1}$ (Figure 4) a value comparable to that of Ti-catalyzed $\mathrm{NaAlH}_{4}{ }^{35,36}$ However in "19-30 nm NaAlH 4 ", no Ti was present as a catalyst. Thus, solely by reducing the particle size to the nanometer range, the activation energy decreased to the same value as ball milled $\mathrm{TiCl}_{3}-\mathrm{NaAlH}_{4}$.

The activation energy lowered to an unprecedented value of $58 \mathrm{~kJ} \cdot \mathrm{mol}^{-1}$ when the $\mathrm{NaAlH}_{4}$ particle size was decreased to $2-10 \mathrm{~nm}$. The relation between activation energies and particle size, i.e., a size-performance relationship, is shown in Figure 5. This correlation opens the possibility to link experiment with theoretical calculations on metal hydride nanoclusters, since now the experimental available cluster size is in the same size range 
as those used in the theoretical studies. ${ }^{37-40}$ But most importantly, the correlation is an advance that is applicable to other hydrogen storage materials as well.

An explanation for the reported particle size dependence for $\mathrm{H}_{2}$ desorption can be deduced from the calculations that have been performed by Vegge on the stability of the $\mathrm{NaAlH}_{4}$ surfaces. ${ }^{40}$ It appears that open surfaces desorb hydrogen with a lower activation energy than the most densely packed (001) surface. Thus, a possible rationale for our reported particlesize dependence of the activation energy resides with a change of the structure of the $\mathrm{NaAlH}_{4}$ surface with particle size. Smaller particles are expected to expose a lower fraction of (001) planes and a higher fraction of more open planes as well as corners and edges, which all lead to a lower activation energy for hydrogen desorption. Additionally, the reduction of the particle size leads to an increase in the external surface area of the alanate, which increases the number of sites where the hydrogen can desorb from. The larger number of (idententical) desorption sites is expected to enhance the rate of desorption but not to lower the activation energy.

For hydrogen desorption in (Ti-catalyzed) bulk alanate particles, the rate determining step has been established to be the mass transfer in the solid state. ${ }^{41}$ Various studies propose different rate determining steps, such as nucleation and growth, ${ }^{42}$ creation of vacancies, ${ }^{43}$ or diffusion of hydrogen containing species. ${ }^{44}$ In contrast to bulk $\mathrm{NaAlH}_{4}$, hydrogen desorption from nano- $\mathrm{NaAlH}_{4}$ involves a significantly shortened mass transfer length in the solid state. This might lead to a shift in the rate determining step from mass transfer in the solid state for bulk samples to hydrogen desorption from the surface for the nano- $\mathrm{NaAlH}_{4}$.

The generally accepted target from the Department of Energy indicates that that an ideal automotive storage tank liberates $\mathrm{H}_{2}$ from -30 to $85{ }^{\circ} \mathrm{C}$. The often studied Ti-catalyzed $\mathrm{NaAlH}_{4}$ has not met this target in a scale-up study. ${ }^{45}$ However for " $2-10$ $\mathrm{nm} \mathrm{NaAlH} 4, ", T_{\max }$ ranged from 40 to $70{ }^{\circ} \mathrm{C}$ (Figures 3 and 4 ). These are, to the best of our knowledge, the lowest reported desorption temperatures for $\mathrm{NaAlH}_{4}$ and indicate that the target is now within reach and nanosized $\mathrm{NaAlH}_{4}$ has potential for application. The loading of the $2-10 \mathrm{~nm} \mathrm{NaAlH} 4$ particles in this paper was $2 \mathrm{wt} \%$ on the CNF and has to be increased for automotive applications. This might be achieved by encapsulation of the $\mathrm{NaAlH}_{4}$ in nanocavities rather than the here-reported deposition of $\mathrm{NaAlH}_{4}$ on the convex surface of the nanofibers.

For application, reloading of the $\mathrm{NaAlH}_{4}$ after $\mathrm{H}_{2}$ extraction must be achieved at low $\mathrm{H}_{2}$ pressure. We studied the uptake

(37) Marashdeh, A.; Olsen, R. A.; Løvvik, O. M.; Kroes, G. J. Chem. Phys. Lett. 2006, 426, 180-186.

(38) Marashdeh, A.; Olsen, R. A.; Løvvik, O. M.; Kroes, G. J. J. Phys. Chem. C 2007, 111, 8206-8213.

(39) Wagemans, R. W. P.; van Lenthe, J. H.; de Jongh, P. E.; van Dillen, A. J.; de Jong, K. P. J. Am. Chem. Soc. 2005, 127 (47), 16675-16680.

(40) Vegge, T. Phys. Chem. Chem. Phys. 2006, 8, 4853-4861.

(41) Colbe, J. M. B. V.; Schmidt, W.; Felderhoff, M.; Bogdanovic, B.; Schüth, F. Angew.Chem., Int. Ed. 2006, 45 (22), 3663-3665.

(42) Kiyobayashi, T.; Srinivasan, S. S.; Sun, D.; Jensen, C. M. J. Phys. Chem. A 2003, 107, 7671-7674.

(43) Palumbo, O.; Paolone, A.; Cantelli, R.; Jensen, C. M.; Sulic, M. J. Phys. Chem. B 2006, 110, 9105-9111.

(44) Lohstroh, W.; Fichtner, M. Phys. Rev. B: Condens. Matter 2007, 75, 184106.

(45) Jensen, J. O.; Li, Q.; He, R.; Pan, C.; Bjerrum, N. J. J. Alloys Compd. 2005, 404-406, 653-656.

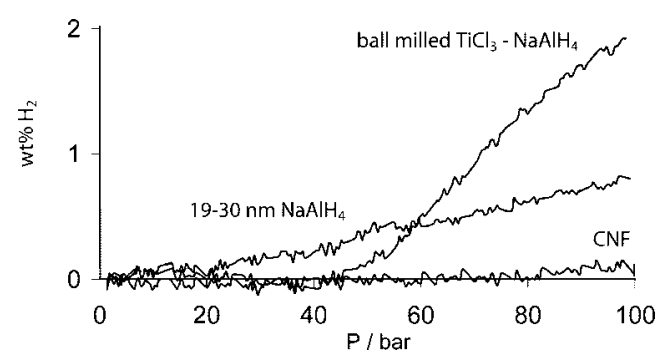

Figure 6. $\mathrm{H}_{2}$ uptake for the first absorption step at $115^{\circ} \mathrm{C}$ for $19-30 \mathrm{~nm}$ $\mathrm{NaAlH}_{4}$ compared to the uptake from ball milled $\mathrm{TiCl}_{3}-\mathrm{NaAlH}_{4}$ and pure CNF. $\Delta P / \Delta t=1.38 \mathrm{bar} \cdot \mathrm{min}^{-1}$.

characteristic of "19-30 nm $\mathrm{NaAlH}_{4}$ " as a function of $\mathrm{H}_{2}$ pressure at $115^{\circ} \mathrm{C}$ (Figure 6). For reference, the pure support material (CNF) was included which did not absorb $\mathrm{H}_{2}$ from 0.1 to 100 bar. The " $19-30 \mathrm{~nm} \mathrm{NaAlH} 4$ " started to absorb $\mathrm{H}_{2}$ from a relatively low $\mathrm{H}_{2}$ pressure of 20 bar. Please note that a typical catalyzed $\mathrm{NaAlH}_{4}$ (ball milled $\mathrm{TiCl}_{3}-\mathrm{NaAlH}_{4}$ ) absorbed $\mathrm{H}_{2}$ starting from 45 bar (Figure 6). It was also observed that the $\mathrm{H}_{2}$ uptake from " $19-30 \mathrm{~nm} \mathrm{NaAlH}{ }_{4}$ " was lower than the total hydrogen capacity $\left(5.6 \mathrm{wt} \% \mathrm{H}_{2}\right)$. A reason for the lower loading capacity might be that the sodium hydride and aluminum particles were physically separated at the CNF surface that hampered recombination of the $\mathrm{NaH}$ and $\mathrm{Al}$ to the $\mathrm{NaAlH}_{4}$. The previously mentioned encapsulation, i.e., confining the $\mathrm{NaAlH}_{4}$ in nanocavities, might overcome this as well.

\section{Conclusion}

In summary, a quantitative relation is found between the activation energy for $\mathrm{H}_{2}$ desorption and the particle size of $\mathrm{NaAlH}_{4}$ varying from $116 \mathrm{~kJ} \cdot \mathrm{mol}^{-1}$ for $1-10 \mu \mathrm{m}$ particles to $80 \mathrm{~kJ} \cdot \mathrm{mol}^{-1}$ for $19-30 \mathrm{~nm}$ particles, to $58 \mathrm{~kJ} \cdot \mathrm{mol}^{-1}$ for $2-10 \mathrm{~nm}$ particles, the latter being lower than that for Ti-catalyzed $\mathrm{NaAlH}_{4}$. For the 2-10 nm particles, the $\mathrm{H}_{2}$ desorption temperature was below 70 ${ }^{\circ} \mathrm{C}$, therewith meeting the target from the Department of Energy for $\mathrm{H}_{2}$ release. Moreover, after desorption the nano- $\mathrm{NaAlH}_{4}$ showed uptake under relatively low $\mathrm{H}_{2}$ pressures (starting at 20 bar) which can lead to the development of safer, more economical and lighter storage tanks. The nanoparticles reported in this paper were noncatalyzed, and the improvement in activation energies and absorption properties could be solely accounted by reducing the $\mathrm{NaAlH}_{4}$ particle size. The size-performance relationship reported provides new avenues for other hydrides, such as other complex metal hydrides and amides, which contain a higher weight fraction of hydrogen.

Acknowledgment. The authors acknowledge Marjan VersluijsHelder, Cor van der Spek, and Ad Mens for SEM, TEM, and XPS measurements, respectively. NWO/ACTS is acknowledged for funding (Project Number 053.61.02). Dr. Petra de Jongh and Dr. Andy Beale are thanked for their input to the manuscript. Vincent Koot and Fred Broersma are acknowledged for their assistance with TPD and Rubotherm measurements.

Supporting Information Available: Influence of $\mathrm{NaAlH}_{4}$ loading and drying. This material is available free of charge via the Internet at http://pubs.acs.org.

JA710667V 